\title{
Determination of the Effect of Humic Acid on Growth and Development Parameters of Parsley (Petroselinum sativum Hoffm.) Grown in Boron Soil
}

\author{
Tuncay TURSUN ${ }^{1}$, Şener AKINCI ${ }^{2 *}$ Esin BOZKURT ${ }^{3}$ \\ ${ }^{1}$ Marmara University, Institute of Pure and Applied Sciences Ziverbey, Kadikoy, Istanbul, Turkey; tuncaytursun@gmail.com \\ ${ }^{2}$ Marmara University, Faculty of Arts and Sciences, Ziverbey, Kadikoy, Istanbul, Turkey; akinci@marmara.edu.tr(*corresponding author) \\ ${ }^{3}$ Marmara University, Faculty of Engineering, Environmental Engineering, Ziverbey, Kadikoy, Istanbul, \\ Turkey; esin.bozkurt@marmara.edu.tr
}

\begin{abstract}
Boron is an important micronutrient, required for all plant growth, and critical for high yield and quality of crops. The aim of the present research was to determine the effects of boron on pot-grown parsley (Petroselinum sativum Hoffm.). The experimental design consisted of four treatments using Hoagland-Arnon (1950) nutrient solutions with two different boron concentrations (B1 - $15 \mathrm{ppm}$ and B2 - $150 \mathrm{ppm}$ ), each with and without $10 \mathrm{ml}$ humic acid addition (HB1 and HB2), and controls with full strength Hoagland-Arnon solutions. Growth analyses of the parsley revealed that $15 \mathrm{ppm}$ boron application caused an increase in root length leaf fresh and dry weight root fresh and dry weight and leaf area compared to control values. $150 \mathrm{ppm} \mathrm{B} \mathrm{(B2)} \mathrm{concentration} \mathrm{decreased} \mathrm{all} \mathrm{growth} \mathrm{parameters} \mathrm{compared} \mathrm{to} \mathrm{controls.} \mathrm{The} \mathrm{two} \mathrm{humic} \mathrm{acid} \mathrm{treatments} \mathrm{(HB1}$ and HB2) did not increase any of those growth parameters either in controls (C) or in the two boron (B1 and B2) concentrations. Analysis by (ICP-MS) revealed that B content in the leaves increased gradually in B1 and B2, as well as in both humic treatments where in HB2 it increased to $99.38 \%$ compared to B1. In the leaves, Mn, $\mathrm{Zn}$ and Fe contents behaved the same as B, increasing in all treatments, with the amounts in $\mathrm{HB} 2$ being significantly greater than in $\mathrm{C}, \mathrm{B} 1$ and $\mathrm{B} 2$ leaves.
\end{abstract}

Keywords: boron; growth; humic acid; parsley; Petroselinum sativum; nutrient uptake

\section{Introduction}

Boron (B) is a non-metal element with uneven distribution in the earth's crust but widely found in both the lithosphere and hydrosphere, ranging from $5-10 \mathrm{mg} \mathrm{kg}^{-1}$ in rocks (Shorrocks, 1997), and 3-30 $\mathrm{g} \mathrm{kg}^{-1}$ in rivers (Power and Woods, 1997). It increases rock acidity and is associated with organic matter, showing elevated concentrations in some coals (Kabata-Pendias and Pendias, 1999).

In the soil, B combines chemically with oxygen to form several minerals, such as the tourmaline group containing hydroxides and silicates. $\mathrm{B}$ is readily soluble after weathering of rocks, producing common anions such as $\mathrm{BO}_{2}, \mathrm{~B}(\mathrm{OH})_{4}$, $\mathrm{B}_{4} \mathrm{O}_{7}{ }^{2-} \mathrm{H}_{2} \mathrm{BO}^{3}$, of which the last two occur in soil solutions at a $\mathrm{pH}$ above 7 . B is likely retained by clay in soil solutions and its concentration is relatively high, between 67 and $3000 \mathrm{gg} \mathrm{L}^{-1}$ (Kabata-Pendias and Pendias, 2001).

Boron is an essential element for plants, where it is required as a micro-level nutrient. Its mobility is limited in phloem in some species whereas it can move freely in certain plants. For instance, $\mathrm{B}$ is immobile in clementine hybrid of mandarin (Papadakis et al., 2004), however in fruits such as Pyrus, Malus and Prunus genera, which have high sorbitol content, B is mobile in phloem as a B-sorbitol complex molecule (Brown and Hu, 1996). Boron concentration in most soil types is higher under low precipitation or reduced irrigation, due to lack of leaching to deeper layers. At increasing concentrations in the soil, beyond that needed for normal growth, B becomes toxic to the plant (Marschner, 1995; Reid, 2010).

Boron can be absorbed by plants as boric acid $\left(\mathrm{H}_{3} \mathrm{BO}_{3}\right)$ or borate anion $\left(\mathrm{B}(\mathrm{OH})_{4}^{-}\right)$forms (Carter and Gregorich, 2008). The availability of $\mathrm{B}$ to plants is affected by the $\mathrm{pH}$, structure, temperature and organic content (i.e. humus) of soil. $\mathrm{pH}$ has a key role in $\mathrm{B}$ absorption by plants, since $\mathrm{B}$ is present in the form of boric acid while soil is neutral or slightly acidic (Goldberg, 1997; Herrera-Rodriguez et al., 2010).

Generally the mobility of boron is limited among plant organs. Boron has crucial roles such as sugar transport, inducing changes in structural and functional features of 
184

membranes, affecting metabolic pathways of carbohydrates, RNA and indoleacetic acid (IAA), for respiration and phenol metabolism. It is also involved in the formation and stabilization, as well as lignification, of cell walls (Loomis and Durst, 1991). Directly or indirectly, cell division, elongation and photosynthesis in leaves is affected by $\mathrm{B}$ concentration (Parvaiz and Prasad, 2012). Boron is associated with nodule formation in the root of fabaceae members, so affects nitrogen metabolism (Kacar et al., 2006). In plants, $B$ concentration in tissues, and essential mineral nutrients, were affected by transpiration when reduced water transport occurred, resulting in toxic levels of $\mathrm{B}$ being reduced but, also resulting in nutrient deficiencies (Hu and Brown, 1997; Brown and Shelp, 1997).

The understanding of $\mathrm{B}$ toxicity is rather limited and fragmented although it is of considerable agronomic importance. The presence of excessive amounts of $B$ is most common in arid and semiarid regions, which are more commonly affected by salt and alkaline soils compared to lands with B deficiency (Gupta et al., 1985; Gupta, 1993, 2006). It is rather difficult to improve land with excessive $B$ concentration. One of the methods of improving soil highly contaminated with $\mathrm{B}$ is to grow plants resistant to $\mathrm{B}$ toxicity, and the other is to wash out the soil with water which has a very low level of B (Nable et al., 1997). The visible common symptoms of $B$ toxicity are the appearance of chlorotic and/or necrotic spots on the tip or edges of older plants leaves (Wilcox, 1960; Nable et al., 1997; Lacey and Davies, 2009).

Humic substances are deposited in soil and sediments, being naturally formed by the decay of organisms such as plants, animals and microorganisms over millions of years. Leonardite is the most important organic source of humic acid. It formed in proximity to lignite beds but differs in that humic substances contain high oxygen, macro-and micro-nutrients (Tipping, 2002).

Humic substances are key components in making soil structure friable. In the soil, bacteria synthesize organic matters (eg. carbohydrates) and humic substances, leading to formation of a soil aggregate together with clay and silt. These formations help create an ideal crumb structure in the top layer of soil, making it friable which improves tilth and gives more porous openings (Hoffman et al., 1993).

Humic acids (HA) increase cation exchange capacity (CEC) and readily form salts with more than 60 different inorganic minerals available to plants (Pettit, 2004; Stevenson, 1994). The inorganics in the soil are bound to naturally occurring humic acids, which are important for ion exchange and making metal complexes (chelates) which are taken up by roots and through the cell membrane (Tipping, 2002; Kulikova et al., 2005; Akinci, 2011).

The available studies reveal that humic acids promote both plant growth and root development. For instance, in relation to root stimulation, length and dry weight of root increase in maize (Sharif et al., 2002; Eyheraguibel et al., 2008), in Helianthus annuus L. (Kolsarici et al., 2005), root dry weight increase in tomato and cucumber (Atiyeh $e t$ al., 2002); root development in ryegrass (Bidegain et al., 2000), root fresh and dry weight increase in tomato and eggplant (Dursun et al., 1999), and positive effect on tomato root fresh and dry weights (Adani et al., 1998).
Humic application positively affects mineral nutrient absorption by roots in some plants, such as enhanced uptake of nitrogen, phosphorus, $\mathrm{K}^{+}, \mathrm{Ca}^{2+}, \mathrm{Cu}^{2+}, \mathrm{Mn}^{2+}, \mathrm{Zn}^{2+}$ and $\mathrm{Fe}^{3+}$ in maize (Eyheraguibel et al., 2008); similarly in maize $\mathrm{Zn}^{2+}, \mathrm{Fe}^{3+}, \mathrm{Mn}^{2+}$ and $\mathrm{Cu}^{2+}$ (Sharif et al., 2002); in ryegrass increased nitrogen, potassium, copper and manganese content (Bidegain et al., 2000). For tomatoes grown in hydroponic cultures prepared with peat- or leonarditederived humic acids, at concentrations of $20 \mathrm{mg} \mathrm{L}^{-1}$ and 50 $\mathrm{mg} \mathrm{L}^{-1}$, the iron content in the roots increased by $113 \%$ and $123 \%$ respectively for peat-sourced humic acid, and by $135 \%$ and $161 \%$ for leonardite-derived humic treatment (Adani et al., 1998).

HA effects on plant growth have been reported by various researchers. Studies indicate that HA causes increased weights of above-ground parts of plants such as common wheat (Triticum aestivum L.) (Malik and Azam, 1985); sunflower (Helianthus annuus L.) (Kolsarici et al., 2005); strawberry (Fragaria ananassa v. Tribute); tomato (Lycopersicon esculentum v. Rutgers), marigold (Tagetes patula v. Antigua Gold F1), pepper (Capsicum annuum grossum v. King Arthur) (Arancon et al., 2003); corn (Zea mays L.) (Eyheraguibel et al., 2008; Tan and Nopamornbodi, 1979).

Humic acid caused increases in dry weights of leaf and stem of maize of $53 \%$ and $100 \%$ repectively (Eyheraguibel $e t$ al., 2008). The same study found that adding HA to maize seedlings increased stem length by $72.5 \%$. In tomato plants, when $\mathrm{HA}$ and $\mathrm{N}, \mathrm{P}, \mathrm{K}$ fertilizers were applied together the number, fresh and dry weights of leaves as well as quantity and quality of fruits increased (Abdel-Mawgout et al., 2007). According to Ferrara et al. (2007) application of HA to grape enhanced stem length and enlarged fruit size and weight compared to controls. In sunflower (Helianthus annuus L.), HA treatment increased stem length, and fresh and dry weights of seedlings (Kolsarici et al., 2005). Sharif $e t$ al., (2002) stated that 50 and $100 \mathrm{mg} / \mathrm{kg}$ HA derived from lignites and applied with N, P, K caused 20\% and 23\% increases in maize stem weight grown in pots.

The effects of HA on mineral constituents of various plants has been reported by many scientists. For instance, Mackowiak et al. (2001) revealed that HA enhanced the uptake of $\mathrm{Fe}, \mathrm{Cu}$ and $\mathrm{Zn}$ in the leaves of wheat (Triticum aestivum $\mathrm{L}$.) grown in a hydroponic medium. In maize, $\mathrm{HA}$ and $\mathrm{N}, \mathrm{P}, \mathrm{K}$ application increased $\mathrm{N}$ content in the plant and soil, and the uptake of micronutrients such as $\mathrm{Zn}, \mathrm{Fe}$, $\mathrm{Mn}$ and $\mathrm{Cu}$ in seedlings grown in a pot experiment (Sharif et al., 2002). Bidegain et al. (2000) reported that using poplar sawdust as an HA source for ryegrass increased $P$ content in the leaves, with an accompanying increase in leaf dry weight and enhanced uptake of $\mathrm{N}, \mathrm{K}, \mathrm{Cu}$ and $\mathrm{Mn}$. Different concentrations of HA application to tomato and egg plant caused increased N, P, K, Na, Mg, Ca, Mn, Fe, Zn and $\mathrm{Cu}$ content in the leaves compared to control plants (Dursun et al., 1999). In tomato (Lycopersicom esculentum L.) grown in hydroponic medium and treated with HA prepared from peat or leonardite, Adani et al. (1998) found that the former sourced HA caused increased N, P, Fe and $\mathrm{Cu}$ and the latter increased N, P and Fe uptake. The most 
appreciable nutrient was $\mathrm{Fe}$, in which concentrations of 20 $\mathrm{mg} \mathrm{L}^{-1}$ and $50 \mathrm{mg} \mathrm{L}^{-1}$ of the hydroponics peat humic increased $\mathrm{Fe}$ by $41 \%$ and $33 \%$ and leonardite caused increases of $31 \%$ and $46 \%$ compared to controls respectively. Another study with the tomato revealed that $1280 \mathrm{mg} / \mathrm{l}$ of HA enhanced the contents of P, K, Ca, Mn, $\mathrm{Fe}, \mathrm{Mg}$ and $\mathrm{Z}$ in the stem of tomato seedlings significantly (David et al., 1994). Fagbenro and Agboola (1993) stated that using three different HA concentrations on teak (Tectona grandis L.) increased uptake of the nutrients P, K, $\mathrm{Mg}, \mathrm{Ca}, \mathrm{Zn}, \mathrm{Fe}$ and $\mathrm{Cu}$, but decreased $\mathrm{Mn}$ in the seedlings grown in growth room conditions.

Parsley (Petroselinum sativum Hoffm.) is a very common and popular aromatic culinary herb and is cultivated in many parts of the world. It is a biennial plant belonging to the Apiaceae family. In Turkey, approximately $40 \%$ of commercially produced parsley, or 58.190 tonnes, was grown in Hatay province during the 2016 season (BUGEM, 2017).

The objectives of the present study were to assess the effect of HA on parsley under two different boron concentrations and to determine the uptake of essential nutrients $\left(\mathrm{Na}^{+}, \mathrm{K}^{+} \mathrm{Fe}^{3+}, \mathrm{Zn}^{2+}, \mathrm{Ca}^{2+}, \mathrm{Mn}^{2+}, \mathrm{Mg}^{2+}\right.$ and $\left.\mathrm{B}^{3+}\right)$ in the leaves of plants grown in pot experiments during 20132014.

\section{Materials and Methods}

In the experiment, seeds of parsley (Petroselinum sativum Hoffm.) 'Giant of Italy' cultivar, which has strongly aromatic leaves and prefers to grow in high moisture soil and a warm climate, were obtained from Vilmorin trade mark by Anadolu seed production and marketing company. The liquid Humic (BIOTOTAL is a trade product of Genta LTD, Turkey) which was used in the present study, contains organic, humic, fulvic and water soluble $\mathrm{K}_{2} \mathrm{O}$ ratios as given in Table 1.

\section{Growing conditions}

The seeds of parsley were planted in plastic pots containing a 3:1 mixture of torf (GARDOL) and perlite (Taşper Perlit San.Tic. Ltd. Şti. - www.tasper.com.tr). After a month, the germinated plantlets were transferred into plastic pots of $10 \mathrm{~cm}$ diameter and $8 \mathrm{~cm}$ height, each containing $130 \mathrm{~g}$ of the same mixture of growing media. The experimental sets were prepared in five blocks each of seven replicates with four individual plants. These were arranged in a completely randomized block design with seven replicates for each of five treatments as follows: controls (C) containing only Hoagland-Arnon (1950); two boron concentrations (15 and $150 \mathrm{ppm}$, denoted B1 and B2 respectively); and two treatments with the same two boron concentrations plus $10 \mathrm{~mL}$ humic acid (HB1 and HB2)

Table 1. Humic acid components used

\begin{tabular}{cc}
\hline Components & Volume $(\% \mathrm{w} / \mathrm{w})$ \\
\hline Total organic substances & 15 \\
Total HA+fulvic acid & 15 \\
Water-soluble $\mathrm{K}_{2} \mathrm{O}$ & 3 \\
$\mathrm{pH}$ & $8-10$ \\
\hline
\end{tabular}

(Table 2). Following transfer to pots, the plants were watered with Hoagland alone for two weeks, after which the experimental solutions were applied for a three-week experimental period (Fig. 1).

The pots with a seedling in each were set up as blocks using a completely randomised method (Mead and Curnow, 1983) at $23 \pm 2{ }^{\circ} \mathrm{C}$. The moisture level of the growth medium was maintained at $55 \% \pm 5$ and sets were exposed to 4000-4200 lux plant fluorescence intensity for $14 \mathrm{~h} / 10 \mathrm{~h}$ day and night periods respectively (Akinci et al., 2009). Growth parameters at the harvesting point, 55 days after transplanting, were determined by measuring plant height $(\mathrm{PH})$, root length (RL), leaf area (LA), average leaf area (ALA); fresh weight of leaves (LFW), stalk (SFW), and roots (RFW), with dry weights of leaves (LDW), stalk (SDW) and roots (RDW) evaluated after 24 hours oven drying at $80^{\circ} \mathrm{C}$ to fully remove tissue water.

\section{Nutrient analysis}

The oven-dried leaves of parsley were weighed and then crushed using a mortar and pestle to powderise them according to the method of Kacar (1972). The powder was transferred into an Erlenmeyer flask and $6 \mathrm{ml}$ nitric acid + perchloric acid was added to it. The acid mixture was put in a water bath at $40{ }^{\circ} \mathrm{C}$ for 30 minutes to digest. A $1 \mathrm{ml}$ extract was obtained after the supernatant was removed by heating at $150-180^{\circ} \mathrm{C}$ on a hot plate.

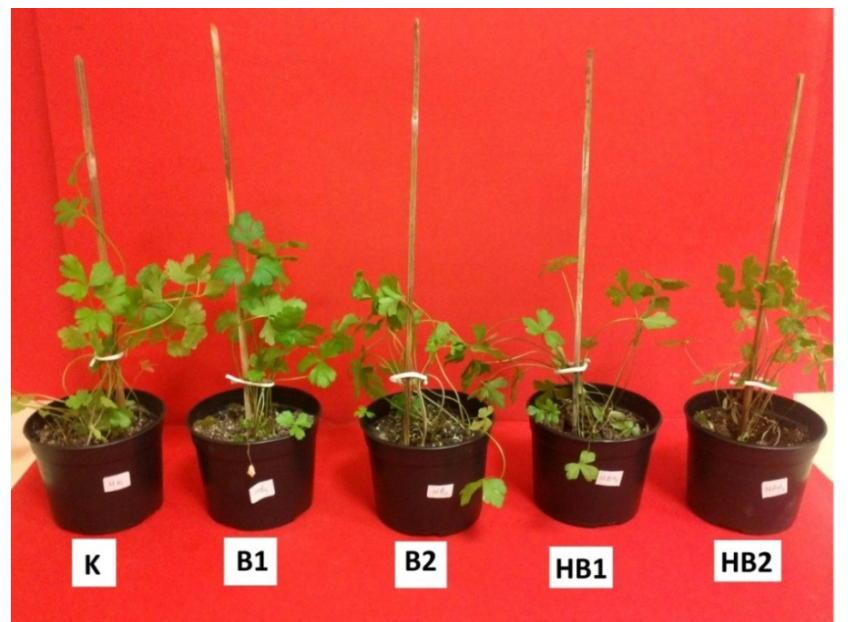

Fig. 1. Parsley treatments in plastic pots at harvesting time. K: Control, B1: 15 ppm boron, B2: 150 ppm boron, HB1: 15 ppm B+ humic acid, HB2: 150 ppm B+ humic acid

Table 2. Boron and humic acid used

\begin{tabular}{|c|c|}
\hline Experimental groups & Contents and preparations \\
\hline Control (C) & $\begin{array}{l}\text { Full strength Hoagland solution (Hoagland- } \\
\text { Arnon, 1950) }\end{array}$ \\
\hline $15 \mathrm{ppm} \mathrm{B} \mathrm{(B1)}$ & $\begin{array}{l}2 \mathrm{ml} \mathrm{B} \text { is dissolved in Hoagland solution and } \\
\text { volume made up } 1 \mathrm{~L}\end{array}$ \\
\hline 150 ppm B (B2) & $\begin{array}{l}20 \mathrm{ml} \mathrm{B} \text { is dissolved in Hoagland solution and } \\
\text { volume made up } 1 \mathrm{~L}\end{array}$ \\
\hline $\begin{array}{l}15 \text { ppm B+ Humic acid } \\
\text { (HB1) }\end{array}$ & $\begin{array}{l}2 \mathrm{ml} \mathrm{B} \text { and } 10 \mathrm{ml} \mathrm{HA} \text { are dissolved in } \\
\text { Hoagland and volume made up } 1 \mathrm{~L}\end{array}$ \\
\hline $\begin{array}{c}150 \text { ppm B +Humic acid } \\
\text { (HB2) }\end{array}$ & $\begin{array}{l}20 \mathrm{ml} \mathrm{B} \text { and } 10 \mathrm{ml} \mathrm{HA} \text { are dissolved in } \\
\text { Hoagland and volume made up } 1 \mathrm{~L}\end{array}$ \\
\hline
\end{tabular}


The residue was made up to $100 \mathrm{ml}$ with distilled water and kept in coloured bottles. $\mathrm{Na}$ and $\mathrm{K}$ were determined by flame photometer (Jenway PEP7) and Fe, Zn, Ca, Mn, Mg, and B by Inductively Coupled Plasma Mass Spectrometry (ICP-MS) (7500A Agilent Technologies) at the Department of Environmental Engineering, Faculty of Engineering, in Marmara University (Fig. 2).

\section{Statistical analysis}

The data from growth parameters and nutrient analyses were subjected to NCSS (Statistical software program, V9 for Windows) for paired-sample T-test. Terms were considered to be significant at the level of $\mathrm{P}<0.05$ (Duncan's MultipleComparison Test to determine significance of differences between means). Means are indicated with standard error ( \pm s.e.) in tables and graphs as error bars.

\section{Results and Discussion}

Effect of Boron and HA on growth of parsley seedlings

The growth parameter results from the present study, for two levels of $\mathrm{B}$, controls (Hoagland), and humic acid treatments, are presented in Table 3 .
B application on parsley caused gradual reduction in plant heights with increasing concentrations (15 and 150 ppm B), by $2.66 \%$ and $15.34 \%$ in B1 and B2 respectively. Both decreases were significant compared to controls at 95\% confidence level. HA addition to boron treatment caused a further reduction plant height, of $19.92 \%$ in HB1 and $18.86 \%$ in HB2 compared with controls. The decreases in both $\mathrm{HB} 1$ and $\mathrm{HB} 2$ were significantly greater than those in $\mathrm{B} 1$ and $\mathrm{B} 2$ at $17.73 \%$ and $4.15 \%$ respectively $(\alpha=0.05)$. The application of $15 \mathrm{ppm} \mathrm{B}$ seemed not to have a harmful effect on parsley, however the ten-fold increase in B concentration in the B2 treatment caused a significant inhibition of growth. The result from B2 agrees with other reports indicating reduction in growth of grain and straw yield in barley and wheat caused by toxic levels of B (Gupta, 1983; Cartwright et al., 1983; Yau and Saxena, 1997). Nable et al. (1990) also stated that plants exposed to high B levels typically show reduced growth of shoots and roots.

There were no positive affect of $\mathrm{HA}$ application mitigating $\mathrm{B}$ toxicity either in $\mathrm{B} 1$ or in $\mathrm{B} 2$ plant heights. There are no reports of HA effects on B toxicity to parsley, however it is known that soil containing humus can increase B uptake by plant roots (Goldberg, 1997).

Table 3. The effect of different treatments on growth parameters in Parsley

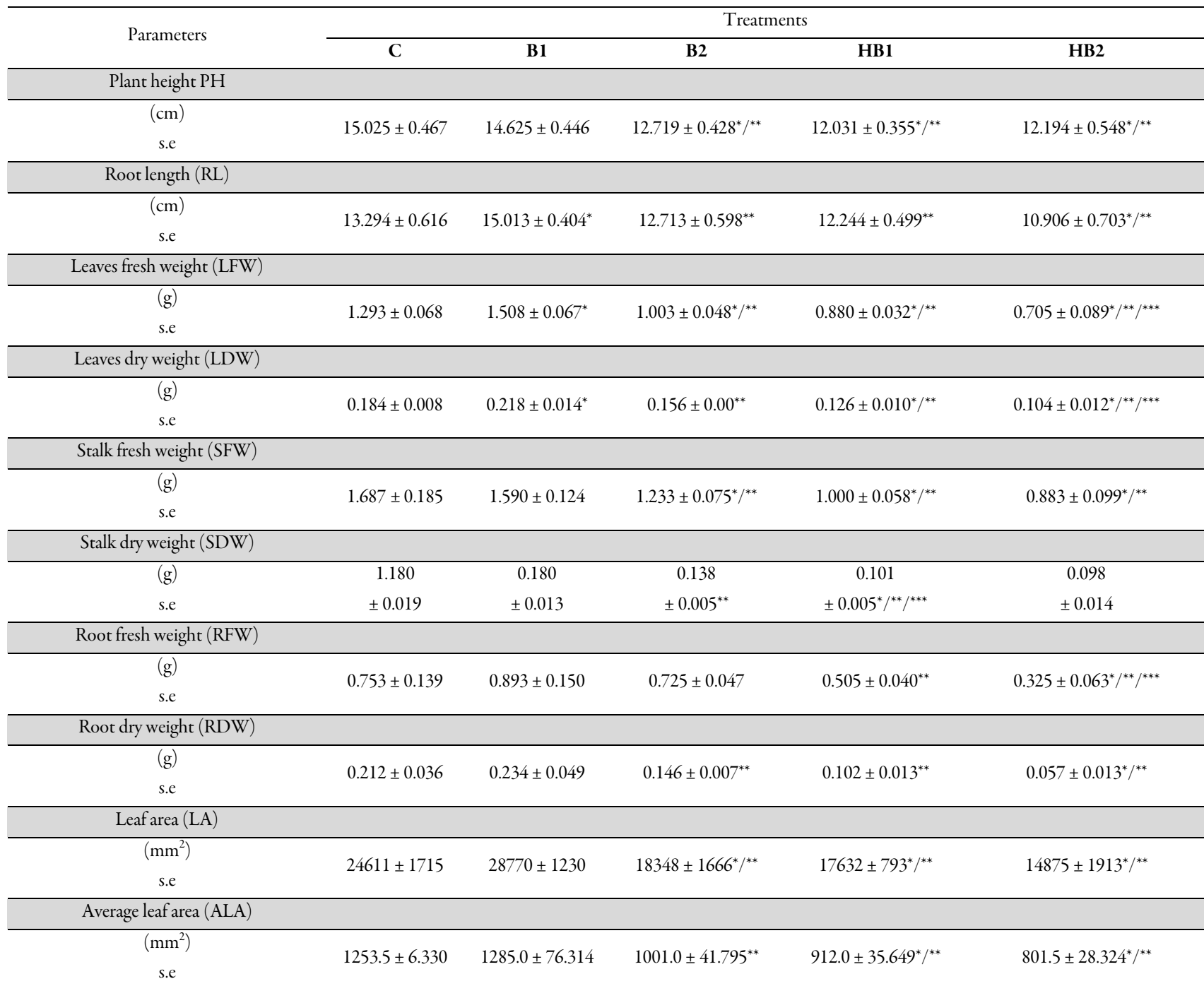


The mean of root length (RL) increased (12.94\%) significantly in the $\mathrm{B} 1$ treatment compared to controls at the $95 \%$ confidence level. Contrary to this, in B2 and the two humic acid treated samples, RL significantly decreased. The decrease in both $\mathrm{HA}$ (HB1 and $\mathrm{HB} 2$ ) was $18.45 \%$ and $14.16 \%$ respectively compared to $\mathrm{B} 1$ and $\mathrm{B} 2$, significant at the level of $\alpha=0.05$. Like PH, RL was affected under high concentration of $\mathrm{B}$, and HA did not reduce the harmful effect of this toxic level of B. 15 ppm B application increased RL significantly, (12.94\%) indicating this concentration may stimulate plant root development. Although known that HA promotes plant root growth, HA was not effective in the presence of $B$.

The present experiment produced LFW of $1.508 \mathrm{~g}$ in $\mathrm{B} 1$ and $1.003 \mathrm{~g}$ in B2. The increase (16.62\%) in B1 was significant to compared to controls, but in contrast LFW decreased significantly in B2 (22.42\%) compared to C and $\mathrm{B} 1$. The effects on dry weights of leaves were similar to those for fresh weights, with an increase in B1 (18.47\%) but decrease in $\mathrm{B} 2$ (15.21\%) with both changes significant compared to $\mathrm{C}$ values. HA treatment did not moderate the B-induced reduction in leaf fresh and dry weights of parsley. The data obtained from B1 (15ppm) showed that the concentration of $\mathrm{B}$ absorbed by roots was less than that causing any toxic effect on leaf growth and development. The toxic level was reached by $150 \mathrm{ppm} \mathrm{B}$ treatment, in which the LFW and LDW decreased significantly compared to $\mathrm{C}$ and $\mathrm{B} 1$. The toxic level effect in leaves did not decline after HA treatments in HB1 and HB2 in which both fresh and dry weight of leaves continued to be lower.

Leaf stalk fresh weight (SFW) slightly decreased (5.4\%) in $\mathrm{B} 1$ although there was no change in dry weight (SDW) in this treatment. In the B2 treatment, significant reductions were found for SFW and SDW (26.97\% and 23.33\% respectively), the former significantly less than $\mathrm{C}$ and $\mathrm{B} 1$ but the latter different only from B1. The reductions were maintained in both HA applications; the decrease in HB1 was $37.10 \%$ in SFW and $43.88 \%$ in SDW, both significant compared to B1 treatments. Fresh and dry weights in HB2 application were $28.32 \%$ and $28.98 \%$ less than B2 respectively, but neither of these was not significant.

Although the toxic concentration of $B$ varies across plant species, the $B$ concentration causing growth inhibition in B2 treatments of parsley seedlings agreed with studies of chickpea (Cicer arietinum L. ) (Bayrak et al., 2005), common bean (Phaseolus vulgaris L.) (Hamurcu and Gezgin, 2007); grain and straw yield of barley and wheat (Gupta, 1983; Cartwright et al., 1983; Yau and Saxena, 1997), and cotton (Gossypium hirsutum L.) (Ahmed et al., 2008).

The root fresh and dry weights behaved like the other parameters, increasing in B1 then decreasing in the other treatments. The root fresh and dry weight increases were $18.59 \%$ and $10.37 \%$ respectively in B1 compared to controls. In B2, both fresh and dry weights reduced by $3.71 \%$ and $31.13 \%$ with the latter (RDW) decrease being significant compared to B1. This finding agrees with the report by Nable et al. (1990) that a reduction in root growth of plants exposed to high B levels is typical.

Humic acid treatments did not induce any recovery after loss of root weight from boron treatments. For HB1 and HB2 fresh and dry weights significantly decreased compared to $\mathrm{B} 1$ roots. The decrease of fresh weights in $\mathrm{HB} 1$ was $43.46 \%$, and in HB2 $55.17 \%$, significant reductions compared to B1 and B2 respectively. Greater reductions were found for dry weights, at $56.14 \%$ and $60.95 \%$ respectively for $\mathrm{HB} 1$ and $\mathrm{HB} 2$, with the former significant compared to B1.

The mean leaf area increased $(16.89 \%)$ in the B1 treatment compared to controls but the increase was not significant at the $95 \%$ confidence level. Contrary to this, the LA in B2 decreased by $25.44 \%$ and was significantly different from $\mathrm{C}$ and B1. On the other hand, like for the other growth parameters, HA did not affect leaf area enlargement, and both HB1 and HB2 decreased by $38.71 \%$ and $18.92 \%$ respectively. The reductions in those were significant compared to controls and B1 treatments.

Average leaf area (ALA) was determined by the average of replicates in pots divided by the number of leaves of those of plants. The ALA figures were similar to LA where B1 had a slight increase (2.51\%). The decrease of ALA in B2 was $20.14 \%$ compared to $\mathrm{C}$, however the reduction was only significantly different from B1 at the $95 \%$ level of confidence. The decrease in HB1 (29.02\%) rather than in $\mathrm{B} 1$, and in HB2 (19.93\%) differed from B2, with the changes in both $\mathrm{HB} 1$ and $\mathrm{HB} 2$ significant compared to both $\mathrm{C}$ and $\mathrm{B} 1$ treatment values. Regarding boron effect on plants, some reports state that reduced growth of various parts of plants, such as roots and shoots, is a typical signal of plants exposed to high B levels (Nable et al., 1990). Reid et al. (2004) stated that the cause of inhibition of growth is mostly related to toxicity of boron accumulating in mature tissues, causing retardation of many cellular processes which is enhance in light by photo-oxidative stress.

There is no existing data on the effect of HA on boron toxicity, although there are some published studies reporting effects of $\mathrm{B}$ alone on plant growth.

The overall finding on growth parameters in B1 and B2 indicating that concentrations of $\mathrm{B}$ over $15 \mathrm{ppm}$ are harmful to parsley plantlets agrees with the findings by Eaton (1944) who stated that more than 15 ppm B content had a toxic effect on parsley.

\section{Effect of $B$ and HA on nutrient content of parsley}

The concentration of selected macro and micro nutrients, namely boron, magnesium, calcium, manganese, iron, zinc, sodium and potassium, were determined in parsley plants grown in C, B1 and B2 solutions with either $15 \mathrm{ppm}$ or $150 \mathrm{ppm}$ boron, with and without added HA. The results from the present study of the nutrient concentrations among the treatments determined at the harvesting stage are presented in Fig. 1.

\section{Boron}

In the present investigation, $\mathrm{B}$ concentration decreased in B1 and B2 applications by $50.59 \%$ and $67.56 \%$ respectively compared to controls, but B2 had a higher B content (33.54\%) than in B1 (Fig. 2.a). This result does not agree with the findings of other studies that $\mathrm{B}$ content mostly increases in plants in correlation with increased B concentration in soil (Eaton, 1944; Jame et al., 1982). Boron availability to plants can occur in two ways: passive and active absorption. According to Brown et al. (2002) and Tanaka and Fujiwara (2007), in the passive process boric 
188

acid absorption by roots takes place where $B$ is available in adequate or excessive quantity and $\mathrm{B}$ passively diffuses across the lipid bilayer. In contrast, active boron uptake by roots occurs under low B conditions (Dannel et al., 2000 and 2002; Stangoulis et al., 2001). It is difficult to evaluate from the present study whether boron was absorbed actively or passively. Although B content was slightly higher in B2 than B1 this was probably a result of the passive absorption mechanism (Brown et al., 2002); Tanaka and Fujiwara (2007)) since B concentration in B1 seemed to be adequate and the B2 concentration was excessive for parsley growth.

The solutions with humic acid, which were prepared by adding $15 \mathrm{ppm}$ and $150 \mathrm{ppm} \mathrm{B}$ in Hoagland, caused increases in the B concentrations in HB1 (81.86\%) and HB2 (100.87\%) compared to B1 and B2 respectively (Fig. 2.a). The increase in $\mathrm{HB} 2$ was significant at the level of $95 \%$ confidence. This result from the present study of a positive effect of HA in parsley leaves supports the report indicating that soil humus level may be linked with higher B absorption by roots (Goldberg, 1997).

\section{Sodium-Potassium}

Sodium content changes in parsley leaves in the treatments were similar to the behaviour of $K$, although the percentage of $\mathrm{Na}$ was lower than $\mathrm{K}$ by around $50 \%$ (Fig. 2.c). The content of $\mathrm{Na}$ varied in all treatments but was highest in $\mathrm{B} 1 . \mathrm{Na}$ increased by $7.35 \%$ in $\mathrm{B} 1$ and decreased by $17.63 \%$ in $\mathrm{B} 2$ compared to controls, of which the latter was significant. $\mathrm{Na}$ accumulation decreased in both $\mathrm{HA}$ treatments. In $\mathrm{HB} 1, \mathrm{Na}$ reduced by $14.53 \%$ without significance, but the reduction in HB2 (1.63\%) was significantly different from B1. It is known that a high amount of $\mathrm{K}$ uptake may cause increased B-deficiency symptoms (Fageria et al., 2011).

The proportionally higher amount of $\mathrm{K}$ compared to $\mathrm{Na}$ content was greatest in $\mathrm{B} 1$, at $19.54 \%$, with values for the other treatments, B2, HB1 and HB2, at 3.67\%, 21.74\% and $4.62 \%$ respectively (Fig. 2.b). Increase of $\mathrm{K}$ accumulation in B1 treatment may be a result of B-K synergistic relationship (Gezgin and Hamurcu, 2006), where $B$ accumulation shows a reduction while $\mathrm{K}$ absorption reaches a maximum level (Cikili et al., 2013).

Application of $\mathrm{HA}$ caused $\mathrm{K}$ in $\mathrm{HB} 1$ to differ significantly from B1 at the level of $95 \%$ confidence level. At the same significant level, the $\mathrm{K}$ content decreased by $4.62 \%$ in HB2 compared to B1. Previous studies revealed that HA application caused accumulation of $\mathrm{K}$ in some plants (Karaman et al., 2012; Mohamed, 2012) but sometimes it may reduce $\mathrm{K}$ uptake (Cimrin et al., 2001). The results obtained from the present study agreed with research stating that $\mathrm{HA}$ increased $\mathrm{K}$ content, particularly the significant difference between $\mathrm{HB} 1$ and $\mathrm{B} 1$.

\section{Calcium}

Ca content in the leaves of parsley was found to be between $828 \mathrm{mg} / \mathrm{g}$ and $1296 \mathrm{mg} / \mathrm{g}$ dry weight (Fig. 2.d). Ca accumulation slightly reduced in B1 but it increased in other treatments in the order B2, HB1, HB2. The increased $\mathrm{Ca}$ concentration in $\mathrm{B} 2$ was only by $3.37 \%$ compared with controls and the difference was not significant. Ca accumulation in $150 \mathrm{ppm}$ boron treated seedlings (B2) increased by $4.07 \%$ without any significance. The HA

\section{B content}

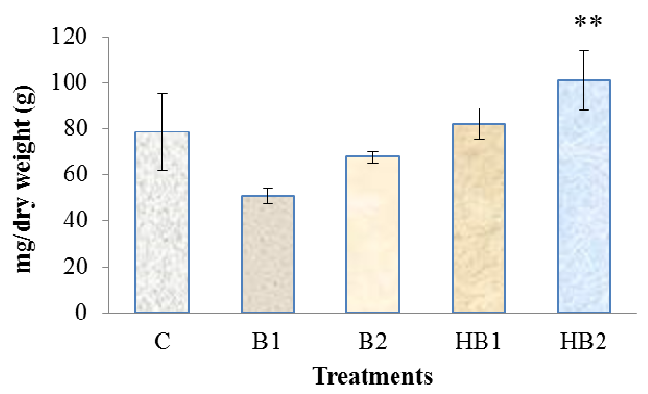

Fig. 2a. Nutrient contents in parsley (Petroselinum sativum Hoffm) leaves under treatments of 15ppm boron (B1), 150 ppm boron (B2), 15 ppm boron thumic acid (HB1), 150 ppm + humic acid (HB2) and Hoagland (C). *: Significantly different from C; ${ }^{* *}$ : Significantly different from B1; ${ }^{* * *}$ : Significantly different from B2

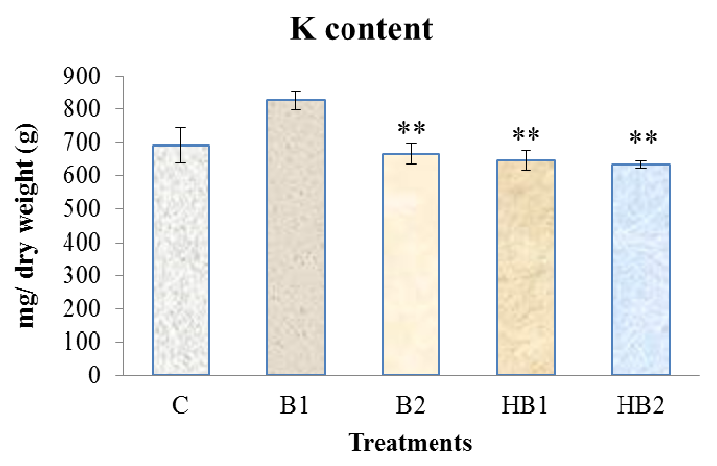

Fig. 2b. Nutrient contents in parsley (Petroselinum sativum Hoffm) leaves under treatments of $15 \mathrm{ppm}$ boron (B1), 150 ppm boron (B2), 15 ppm boron thumic acid (HB1), 150 ppm + humic acid (HB2) and Hoagland (C). *: Significantly different from C; ${ }^{* *}$ : Significantly different from B1; ${ }^{* * *}$ : Significantly different from B2

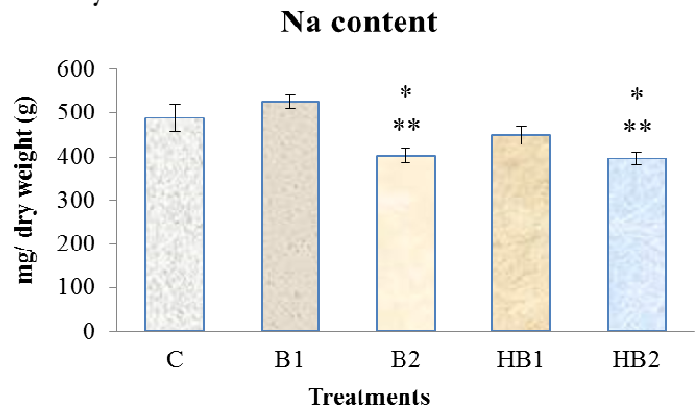

Fig. 2c. Nutrient contents in parsley (Petroselinum sativum Hoffm) leaves under treatments of $15 \mathrm{ppm}$ boron (B1), 150 ppm boron (B2), 15 ppm boron thumic acid (HB1), 150 ppm + humic acid (HB2) and Hoagland (C). *: Significantly different from C; ${ }^{* *}$ : Significantly different from B1; ${ }^{* *}$ : Significantly different from B2

treatments caused increases of $17.00 \%$ in $\mathrm{HB} 1$ and $45.12 \%$ in HB2, however neither was significant at the $95 \%$ confidence level. The accumulation of $\mathrm{Ca}$ has an antagonistic relationship with B (Gezgin and Hamurcu, 2006), and it is known that high levels of calcium increase $B$ deficiency symptoms. A previous report indicated that $\mathrm{B}$ uptake had a negative effect on Ca absorption (Kord et al., 
2010), nevertheless the data obtained from the present study agreed with the study finding that $\mathrm{HA}$ increased $\mathrm{Ca}$ content (Savasturk, 2008). On the other hand, another study found that HA caused a negative effect on Ca uptake on maize seedlings (Cimrin et al., 2001).

\section{Magnesium}

Magnesium content accumulation was small, and similar to Mn, among the nutrients analysed by the present study. This ratio may be related to high levels of Potassium which reduce Mg uptake (Fageria et al., 2011).

The concentration of $\mathrm{Mg}$ increased in B1 treatment which has risen up to $111.11 \%$ where $\mathrm{Mg}$ content increased by only $23.33 \%$ compared to controls but neither change was significant at the 95 confidence level (Fig. 2.e). In terms of $\mathrm{HA}$ application, $\mathrm{Mg}$ content decreased from $114.0 \mathrm{mg} / \mathrm{g}$ in $\mathrm{B} 1$ to $76.7 \mathrm{mg} / \mathrm{g}$ in $\mathrm{HB} 1$, a reduction of $32.71 \%$ which was not significant. In $\mathrm{HB} 2$, the amount of $\mathrm{Mg}$ increased $31.98 \%$ compared to $\mathrm{B} 2$ treatments but this change was also not significant. Since there is an antagonistic relationship between $\mathrm{B}$ and $\mathrm{Mg}$ (Gezgin and Hamurcu, 2006), the increased $\mathrm{B}$ concentration (150 ppm) caused a reduction in uptake of $\mathrm{Mg}$. With $\mathrm{HA}$ addition to $\mathrm{B}$ and Hoagland solutions, the positive changes in $\mathrm{Mg}$ in both $\mathrm{HB} 1$ and $\mathrm{HB} 2$ compared to controls supports previous reports by Savasturk, (2008); Karaman et al., 2012).

\section{Manganese}

Mn concentration changes appeared the same as for iron in all treatments of parsley leaves. Mn content decreased by $18.85 \%$ in B1 while it increased in B2 by $11.42 \%$ compared to controls but the differences were not significant (Fig. 2.f). HA addition affected $\mathrm{Mn}$ absorption significantly $(\alpha=$ $0.005)$ in HB1 (71.43\%) and $55.02 \%$ in HB2 compared to B1 and B2 respectively. Although there was no clear relationship between available $\mathrm{Mn}-\mathrm{B}$ uptake from the soil by plants through synergistic or antagonistic ways (Gezgin and Hamurcu, 2006), the results from the present study agreed with reports by Karaman et al., (2012) which underlined that HA causes increased Mn uptake.

\section{Iron}

$\mathrm{Fe}$ content in parsley leaves was one of highest along with $\mathrm{Ca}, \mathrm{K}, \mathrm{Na}$. Iron accumulated in parsley leaves in B2 and both humic treatments (i.e. HB1 and HB2) compared to controls (Fig. 2.g). Fe concentration showed a slight decrease in B1 (11.83\%) though this was not statistically significant, but increased by $24.79 \%$ in B2 compared to leaves in controls. $\mathrm{HA}$ increased $\mathrm{Fe}$ concentration in both HB1 and HB2 treatments, which differed from B1 and B2 by $77.48 \%$ and $54.95 \%$ respectively. Both HA changes were significant at the $95 \%$ confidence level (Fig. 2.g). Although some reports state that Fe content varies in different species, and generally legumes have more $\mathrm{Fe}$ than grasses, parsley is one example where the Fe accumulation that occurred in the present study increased after HA application.

\section{Zinc}

$\mathrm{Zn}$ changes in parsley leaves were similar to $\mathrm{B}, \mathrm{Fe}$ and $\mathrm{Mn}$, with a slight decrease in B1, and gradually increasing across B2, HB1 and HB2 treatments (Fig. 2.h). The content of $\mathrm{Zn}$ ranged between 63 and $121 \mathrm{mg} / \mathrm{g}$ dry leaf weight. In the present investigations, $\mathrm{Zn}$ concentration decreased by
$18.85 \%$ in $\mathrm{B} 1$ compared to $\mathrm{C}$ but the reduction was not significant The $\mathrm{Zn}$ content was decreased in $\mathrm{B} 1(18.00 \%)$ while it increased by $4.11 \%$ in B2 compared to controls. After humic addition, $\mathrm{Zn}$ concentration increased $50.17 \%$ and $50.12 \%$ in $\mathrm{HB} 1$ and $\mathrm{HB} 2$ treatments respectively, of which the latter was significant from the $\mathrm{Zn}$ contents in $\mathrm{C}$, $\mathrm{B} 1$ and B2 at the confidence level of $95 \%$ (Fig. 2. h). It is known that there is a synergistic relationship between $B$ and $\mathrm{Zn}$ uptake from the soil (Gezgin and Hamurcu, 2006). However, in Citrus aurantifolia L., B content decreased on application of $\mathrm{Zn}$ (Rajaie et al., 2009). Therefore, $\mathrm{Zn}$ application is recommended to reduce B toxicity in boronrich soil but, conversely, decreased $\mathrm{Zn}$ concentration may not result from B application (Adiloglu and Adiloglu, 2006; Rajaie et al., 2009). According to Hosseini et al. (2007) and Aref (2011), in plant tissue, in terms of concentration, boron and zinc are antagonistic. However, Sinha et al. (2000) reported that $\mathrm{Zn}$ and $\mathrm{B}$ had a positive interaction in mustard (Brassica nigra (L.) Koch) and in tomato (Lycopersicon esculentum Mill., cv. 'Lale') $\mathrm{Zn}$ and B treatments increased Zn concentration (Gunes et al., 2000).

The reports from Karaman et al. (2012), Savasturk (2008), and Mohamed (2012) stated that HA causes increase in $\mathrm{Zn}$ absorption, in agreement with the results from the present study which revealed that HA increased $\mathrm{Zn}$ content up to $50 \%$ in both HA applications.

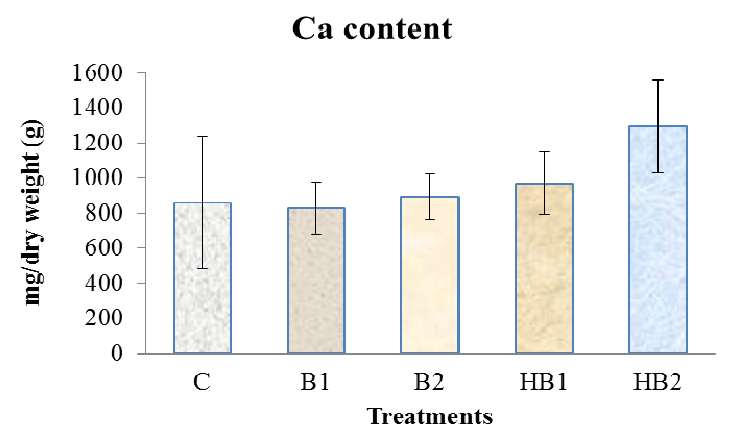

Fig. 2d. Nutrient contents in parsley (Petroselinum sativum Hoffm) leaves under treatments of $15 \mathrm{ppm}$ boron (B1), 150 ppm boron (B2), 15 ppm boron thumic acid (HB1), 150 ppm + humic acid (HB2) and Hoagland (C). *: Significantly different from C; ${ }^{* *}$ : Significantly different from B1; ${ }^{* * *}$ : Significantly different from B2

Mg content

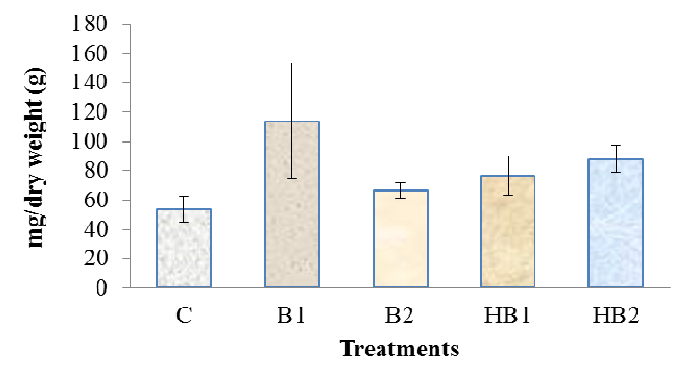

Fig. 2e. Nutrient contents in parsley (Petroselinum sativum Hoffm) leaves under treatments of $15 \mathrm{ppm}$ boron (B1), 150 ppm boron (B2), 15 ppm boron thumic acid (HB1), 150 ppm + humic acid (HB2) and Hoagland (C). *: Significantly different from C; ${ }^{* *}$ : Significantly different from B1; ${ }^{* * *}$ : Significantly different from B2 
190

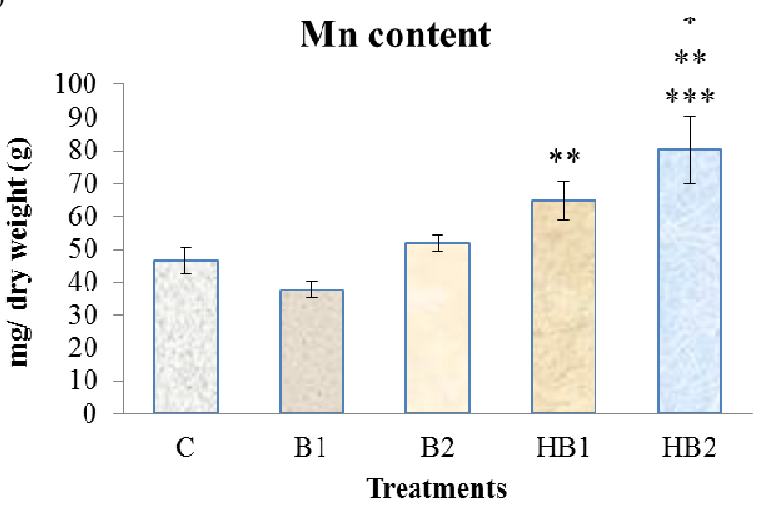

Fig. 2f. Nutrient contents in parsley (Petroselinum sativum Hoffm) leaves under treatments of $15 \mathrm{ppm}$ boron (B1), 150 ppm boron (B2), 15 ppm boron +humic acid (HB1), 150 ppm + humic acid (HB2) and Hoagland (C). * : Significantly different from $\mathrm{C}$; ${ }^{* *}$ : Significantly different from $\mathrm{B} 1$; $^{* * *}$ : Significantly different from B2

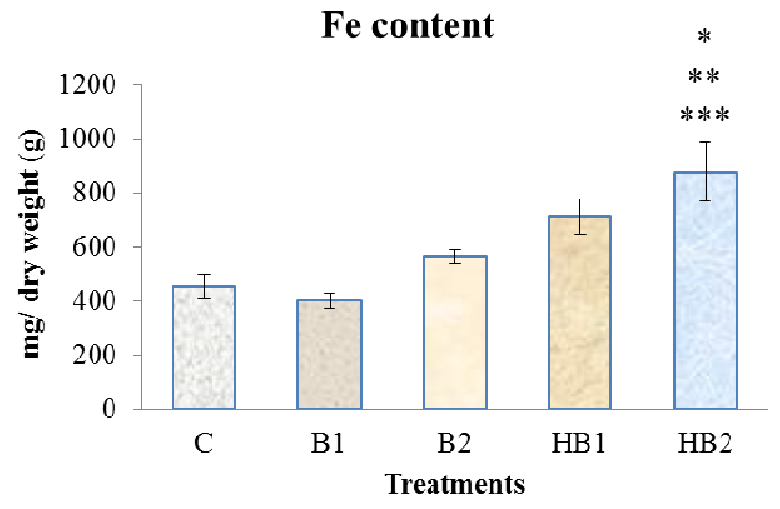

Fig. 2g. Nutrient contents in parsley (Petroselinum sativum Hoffm) leaves under treatments of $15 \mathrm{ppm}$ boron (B1), 150 ppm boron (B2), 15 ppm boron thumic acid (HB1), 150 ppm + humic acid (HB2) and Hoagland (C). * : Significantly different from C; ${ }^{* *}$ : Significantly different from B1; ${ }^{* * *}$ : Significantly different from B2

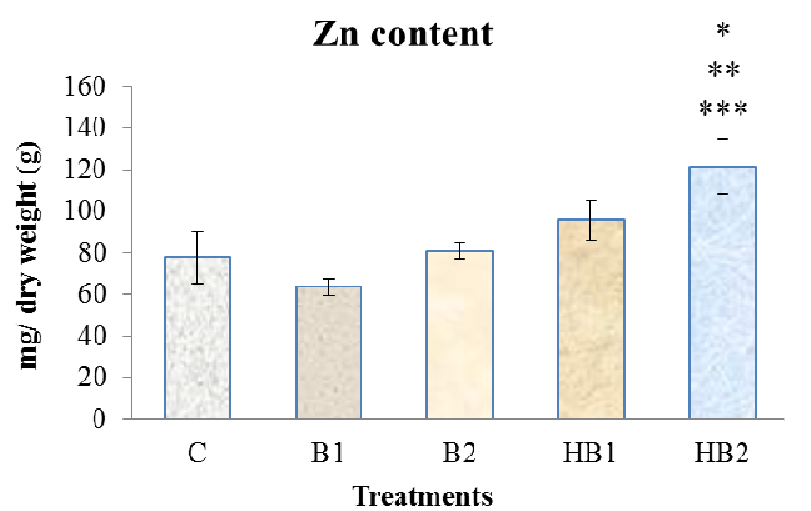

Fig. 2g. Nutrient contents in parsley (Petroselinum sativum Hoffm) leaves under treatments of 15ppm boron (B1), 150 ppm boron (B2), 15 ppm boron thumic acid (HB1), 150 ppm + humic acid (HB2) and Hoagland (C). *: Significantly different from $\mathrm{C}$; ${ }^{* *}$ : Significantly different from B1; ${ }^{* * *}$ : Significantly different from B2

\section{Conclusions}

Boron is a crucial micronutrient and plays an important role in plant growth and development, being mainly involved in carbohydrate metabolism and cell division. Although there are differences in B accumulation from plant to plant, analysis of plant parts, such as tissues in the leaf margins and in the rest of the leaf blade, gives 10 to 50 ppm of the dry weight as an accepted adequate range. According to van Goor and van Lune (1980), the B concentration is relatively higher than other micronutrients and differed in phloem (10 $\left.\mu \mathrm{g} \mathrm{g}^{-1}\right)$ and in leaf tissue (34 $\mu \mathrm{g} \mathrm{g}^{-1}$ ), but it is less than other elements while transported within veins. These findings agree with the present study, which indicated that B caused increase in leaf fresh and dry weights and leaf area in B1 treatments, but B content was found to be less in leaf stalks in B1 application compared to controls. The present study revealed that 15 ppm B application to parsley plants was an adequate amount that promoted plant growth and development in nearly all parameters except plant height and stalk weight, for which the effect of B was unclear. In contrast, $150 \mathrm{ppm}$ $B$ seemed to be an excessive amount that decreased all growth parameters. HA treatments had a very slight effect of reducing the effects of excess $\mathrm{B}$ absorption on growth parameters. Considering plant nutrient composition changes in the parsley leaves, $\mathrm{HA}$ affected absorption of $\mathrm{Ca}$, $\mathrm{Mn}, \mathrm{Fe}$ and $\mathrm{Zn}$ in $\mathrm{HB} 1$ and $\mathrm{HB} 2$ treatments when compared to the boron-only treatments i.e. B1 and B2 respectively. Boron content also increased after $\mathrm{HA}$ application. This finding of HA effect agrees with Goldberg (1997). Szabolcs (1989) stated that increased B accumulation in plant depends on nutrient solution and humus content, and is greater than the plant needs physiologically. $\mathrm{Na}$ and $\mathrm{K}$ concentration were decreased in both HA treatments. As a conclusion, under deficient, adequate or excessive conditions of $\mathrm{B}$, synergistic or antagonistic interaction of $\mathrm{B}$ may affect plant nutrition composition. $\mathrm{B}$ content had a varied effect on the different growth parameters observed, with differing responses related to $B$ concentrations ( $15 \mathrm{ppm}$ and $150 \mathrm{ppm} \mathrm{B}$ ) and HA additions. HA can contribute uptake of certain nutrients from soil, although the ratios absorbed did not seem to be adequate to fulfill requirements of parsley plants for ideal growth and development in the pot experiment.

\section{Acknowledgements}

We wish to thank Agr. Eng. MSc. Hüseyin ÇİMEN for evaluation flame photometer at the Nature Plants and Water Products Research and Application Center (DOBISU), Marmara University. We wish also special thanks to Dr. Ian Milne for his great encouragement during preparing article and English corrections of the text.

\section{References}

Abdel-Mawgoud ASA, Gameh MA, Abdel-Aziz SH, El-Sayed MM (2007). Wheat water relations at various irrigation regimes with modern irrigation systems under climatic condition of Assiut governorate, Upper Egypt.Journal of Agricultural Science 32(7):6051-6066. 
Adani F, Genevini P, Zaccheo P,ZocchiG (1998). The effect of commercial humic acid on tomato plant growth and mineral nutrition. Journal of Plant Nutrition 21:561-575.

Adiloglu A, Adiloglu S (2006). The effect of boron (B) application on the growth and nutrient content of maize in zinc deficient soils. Bulgarian Journal of Agricultural Science 12:387-392.

Ahmed N, Abid M, Ahmad F (2008). Boron toxicity in irrigated cotton (Gossypium hirsutum L.). Pakistan Journal of Botany 40:2443-2445.

Akinci S, Buyukkeskin T, Eroglu AE, Erdogan BE (2009). The effect of humic acid on nutrient composition in broad bean (Vicia faba $\mathrm{L}$.) roots. NotulaeScientia Biologicae 1(1):1-8.

Akinci S (2011). Humik Asitler, Bitki Büyümesi ve Besleyici Alımı [Humic Acids Plant Growth and Nutrient Uptake]. Marmara Üniversitesi Fen BilimleriDergisi 23(1):46-56(In Turkish).

Arancon NQ, Lee S, Edwards A, Atiyeh R (2003). Effects of humic acids derived from cattle, food and paper-waste vermicomposts on growth of greenhouse plants. Pedobiologia 47:741-744.

Aref F (2011). Concentration of zinc and boron in corn leaf as affected by zinc sulfate and boric acid fertilisers in a deficient soil. Life Science Journal 8:26-31.

Atiyeh RM, Lee S, Edwards CA, Arancon NQ, Metzger JD (2002). The influence of humic acids derived from earthworm-processed organic wastes on plant growth. Bioresource Technology 84(1):7-14.

Bayrak H, Onder M, Gezgin S (2005). Bor uygulamasınının nohut (Cicer arietinum L. ) cesitlerinde verim ve bazi verim unsurlarna etkileri [Effects on yield and some yield components of boron application in chickpea (Cicer arietinum L.) varieties]. Selçuk Üniversitesi Ziraat FakültesiDergisi 19(35):66-74(In Turkish).

Bidegain RA, Kaemmerer M, Guiresse M,HafidiM, ReyF, MorardP, Revel JC (2000). Effects of humic substances from composted or chemically decomposed poplar sawdust on mineral nutrition of ryegrass. Journal of Agricultural Sciences 134:259-267.

Brown PH, Hu H (1996). Phloem mobility of boron is species dependent. Evidence for phloem mobility in sorbitol rich species. Annals of Botany 77:497-505.

Brown PH, Bellaloui N, Wimmer MA, Bassil ES, Ruiz J, Hu H, Pfeffer H, Dannel F, Romheld VV (2002). Boron in plant biology. Plant Biology 4:205-223.

Brown PH, Shelp BJ (1997). Boron mobility in plants. Plant and Soil 193: $85-101$.

BUGEM (2017). BUGEM General Directorate of Plant Production. Turkish agricultural statistics for 2017. Republic of Turkey Ministry of Agriculture and Forestry Ankara. Retrieved 2017 April 13 from http://www.tarim.gov.tr/sgb/Belgeler/SagMenuVeriler/BUGEM.pdf (In Turkish).

Carter MR, Gregorich EG (2008). Soil Sampling and Methods of Analysis (2nd ed). CRC Press, Boca Raton.

Cartwright B, Tiller KG, Zarcinas BA, Spouncer LR (1983). The chemical assessment of the boron status of soils. Australian Journal of Soil Research 2:321-332.

Cikili Y, Samet H, Dursun S (2013). Effects of potassium treatment on alleviation of boron toxicity in cucumber plant (Cucumis sativus L). SoilWaterJournal 2:719-726.
191

Cimrin KM, Karaca S, Bozkurt MA (2001). Misır bitkisinin gelisimi ve beslenmesi üzerine hümik asit ve NPK uygulamalarının etkisi [The effect of NPK and humic acid applications on growth and nutrition of corn plant (Zea mays L.)]. Tarim Bilimleri Dergisi 7(2):95-100 (In Turkish).

Dannel F, Pfeffer H, Romheld V (2000). Characterization of root boron pools, boron uptake and boron translocation in sunflower using the stable isotope ${ }^{10} \mathrm{~B}$ and ${ }^{11} \mathrm{~B}$. Australian Journal of Plant Physiology $156: 756-761$.

Dannel F, Pfeffer H, Romheld V (2002). Update on boron in higher plantUptake, primary translocation and compartmentation. Plant Biology 4:193-204.

David PP, Nelson PV, Sanders DC (1994). A humic acid improves growth of tomato seedling in solution culture. Journal of Plant Nutrition $17: 173-184$.

Dursun A, Guvenc I, Turan M (1999). Macro and micro nutrient contents of seedlings andtheir effects on seedling growth in relation to humic acid application. In: Anac D, Martin-Prevel P (Eds). Improved Crop Quality by Nutrient Management. Kluwer Academic Publishers, Dordrecht, Boston, London.

Eaton FM (1944). Deficiency, toxicity, and accumulation of boron in plants. Journal of Agricultural Research 69:237-277.

Eyheraguibel B, Silvestre J, Morard P (2008). Effects of humic substances derived from organic waste enhancement on the growth and mineral nutrition of maize. Bioresource Technology 99:4206-4212.

Fagbenro JA, Agboola AA (1993). Effect of different levels of humic acid on the growth and nutrient uptake of teak seedlings. Journal of Plant Nutrition 16:1465-1483.

Fageria NK, BaligarVC, Jones CA (2011). Growth and mineral nutrition of field crops, 3rd edition. CRC Press, Boca Raton.

Ferrara G, Pacifigo A, Simeone P, Ferrara E (2007). Preliminary study on the effects of foliar applications of humic acids on Italia table grape. XXXth Worl Congress of Vine and Wine, Budapest, Hungary (Vol 165).

Gezgin S, Hamurcu M (2006). The importance of the nutrient elements interaction and the interactions between boron with the other nutrients elements in plant nutrition. Selçuk University, Yearbook of the Faculty of Agriculture, pp 2431 (In Turkish).

GoldbergS(1997). Reactions of boron with soils. Plant and Soil 193:35-48.

Gunes A, Alpaslan M, Cikili Y, Ozcan H (2000). The effect of zinc on alleviation of boron toxicity in tomato plants (Lycopersicon esculentum L.). Turkish Journal of Agriculture and Forestry 24:505-509.

Gupta UC (1983). Boron deficiency and toxicity symptoms for several crops as related to tissue boron levels. Journal of Plant Nutrition 6:387-395.

Gupta UC (1993). Boron and its role in crop production. CRC Press: Boca Raton, FL.

Gupta UC, Jame YW, Campbell CA, Leyshon AJ, Nocholaivhuk W (1985). Boron toxicity and deficiency: A review. Canadian Journal of Soil Science 65(3):381-409.

Gupta UC (2006). Chapter 8. Boron. In: Hand book of plant nutrition. Barker AV, Pilbeam DJ (Eds) CRC Press, Boca Raton, FL, USA pp 241-277.

Hamurcu M, Gezgin S (2007). Bor ve çinko uygulamasının bazı bodur fasulye (Phaseolus vulgaris L.) genotiplerinin biyolojik verim değerlerine 
192

etkisi [Effect of boron and zinc applications on biomass values of dwarf bean (Phaseolus vulgaris L.) genotypes]. Selçuk Üniversitesi Ziraat Fakültesi Dergisi21(41):11-22(In Turkish).

Herrera-Rodríguez MB, González-Fontes A, Rexach J, Camacho-Cristóbal JJ, Maldonado JM, Navarro-Gochicoa MT (2010). Role of boron in vascular plants and response mechanisms to boron stresses. Plant Stress 4:115-122.

Hoagland DR, Arnon DI (1950). The water-culture method for growing plants without soil. California Agricultural Experimental Station Circular 347 (Univ California, Berkeley).

Hoffman GL, Nikols DJ, Stuhec S, Wilson RA (1993). Evaluation of leonardite (humalite) resources of Alberta. Open File Report 1993-18 [Online]. Alberta Research Council. Available: http://www.ags.gov.ab.ca/publications/OFR/PDF/OFR_1993_18.p df.

Hosseini SM, Maftoun M, Karimian N, Rounaghi A, Emam Y (2007). Effect of zinc $\times$ boron interaction on plant growth and tissue nutrient concentration of corn. Journal of Plant Nutrition 30:773-781.

Hu H, Brown P (1997). Absorption of boron by plant roots. Plant Soil 193:49-58.

Jame YW, Nicholaichuk W, Leyshon AJ, Campbell CA (1982). Boron concentration in the soil solution under irrigation: A theoretical analysis. Canadian Journal ofSoil Science 62:461-470.

Kabata-Pendias A, Pendias H (1999). Biogeochemistry of trace elements, 2nded. Wyd. Nauk PWN, Warsaw.

Kabata-Pendias A, Pendias H (2001). Trace elements in soils and plants, 3rd Edn. CRC Press, Boca Raton, Florida, USA.

Kacar B (1972). Chemical analyses of soil and plant. Press of Ankara University Agricultural Faculty 53 (In Turkish).

Kacar B, Katkat AV, OzturkS (2006). Bitki Fizyolojisi [Plant Physiology]. 2. Baski Nobel Yayin Dagitim. Yayin No: 848 (In Turkish).

Karaman MR, Turan M, Ylldırım E, Gunes A, Esringu A, Demirtaş A, Gürsoy A, Dizman M, Tutar A, Kilinc H (2012). Ca ve B-Humat bileşiklerinin domates (Lycopersicon esculentum L.) bitkisinin verim parametreleri ile klorofil ve stoma gecirgenligi üzerine etkilerinin belirlenmesi [Determination of effects calcium and boron humate on tomato (Lycopersicon esculentum L.) yield parameters, chlorophyll and stomatal conductivity]. Sakarya Üniversitesi Fen-Edebiyat Dergisi 14(1):177-185(In Turkish).

Kolsarici O, Kaya MD, Day S, Ipek A, Uranbey S (2005). Effects of humic acid rate on emergence and seedling growth of sunflower (Helianthus annuus L.). Ziraat Fakultesi Dergisi, Akdeniz Universitesi (2):151-155 (In Turkish).

Kord M, Derakhshan L, Memarian H, Tajabadipour A (2010). Effects of high boron concentration on boron uptake and growth of pistachio seedlings. 19th World Congress of Soil Science, Soil Solutions for a Changing World 1-6 August 2010, Brisbane, Australiapp 150-153.

Kulikova NA, Stepanova EV, Koroleva OV (2005). Mitigating activity of humic substances: Direct influence on biota. In: Use of humic substances to remediate polluted environments: From theory to practice. NATO Science Series IV: Erath and Environmental Series, PerminovaIV(Eds). Kluwer Academic Publishers, USA, pp 285-309.

Lacey A, Davies S (2009). Boron toxicity in WA soils. WA Department of
Agriculture and Food Farmnote, 388/2009. Government of Western Australia.

Loomis WD, Durst RW (1991). Boron and cell walls. In: Randall DD, Blevins DG, Miles CD (Eds). Current topics in plant biochemistry and physiology, Vol 10. University of Missouri, Columbia, pp 149-178.

Mackowiak C, Grossl P, Bugbee B (2001). Beneficial effects of humic acid on micronutrient availability to wheat. Soil Science Society of America Journal 65:1744-1750.

Malik KA, Azam F (1985). Effects of humic acids on wheat (Triticum aestivum L.) seedling growth. Environmental and Experimental Botany $25: 245-252$.

Marschner H (1995). Mineral Nutrition of Higher Plants, 2nd. Academic Press, London.

Mead R, Curnow RN (1983). Statistical methods in agricultural and experimental biology. Chapman and Hall,London.

Mohamed H(2012). Effects of humic acid and calcium forms on dry weight and nutrient uptake of maize plant under saline condition. Australian Journal of Basic and Applied Sciences 6(8):597-604.

Nable RO, Banuelos GS, Paull JG (1997). Boron toxicity. Plant and Soil 193:181-198.

Nable RO, Cartwright B, Lance RC (1990). Genotypic differences in boron accumulation in barley: Relative susceptibilities to boron deficiency and toxicity. In: El Bassam N, Dambroth M, Loughman B (Eds). Genetic Aspects of Plant Mineral Nutrition. Kluwer Academic Publishers, Dordrecht, The Netherlands pp 243-251.

Papadakis IE, Dimassi KN, Bosabalidis AM, Therios IN, Patakas A, Giannakoula A (2004). Boron toxicity in 'Clementine' mandarin plants grafted on two rootstocks. Plant Science 166:539-547.

Parvaiz A, Prasad M (2012). Abiotic stress responses in plants. Springer Science+Business Media. Library of Congress Control Number: 2011940823.

Pettit RE (2004). Organic matter, humus, humate, humic acid, fulvic acid and humin: their importance in soil fertility and plant health. Retrieved 2017 January 20 from www.humate.info/mainpagehtm.

Power PP, Woods WG (1997). The chemistry of boron and its speciation in plants. Plant Soil 193:1-13.

Rajaie M, Ejraie AK, Owliaie HR, Tavakoli AR (2009). Effect of zinc and boron interaction on growth and mineral composition of lemon seedlings in a calcareous soil. International Journal of Plant Production 3(1):39-49.

Reid R(2010). Can we really increase yields by making crop plants tolerant to boron toxicity? Plant Science 178:9-11.

Reid RJ, Hayes JE, Post A, Stangoulis JCR, Graham RD (2004). A critical analysis of the causes of boron toxicity in plants. Plant Cell and Environment 25:1405-1414.

Savasturk O (2008). Effects of soil- and foliar-applied humic acids and phosphorus on the growth and mineral nutrient content of eggplant. MSc thesis, Ankara University, Graduate School of Natural and Applied Sciences, Ankara, Turkey.

Sharif M, Khattak RA, Sarir MS (2002). Effect of different levels of lignitic coal derived humic acid on growth of maize plants. Communications in Soil Science and Plant Analysis 33(19-20):3567-3580.

Shorrocks V (1997). The occurrence and correction of boron deficiency. 
Plant and Soil 193:121-148.

Sinha P, Jain R, Chatterjee C (2000). Interaction effect of boron and zinc on growth and metabolism of mustard. Communications in Soil Science and Plant Analysis 3:41-49.

Stangoulis JC, Reid RJ, Brown PH, Graham RD (2001). Kinetic analysis of boron transport in Chara. Planta 213:142-146.

Stevenson FJ (1994). Humus chemistry: Genesis, composition, reactions. 2nd.Edition, John Wiley and Sons, Inc, New York. 285.

Szabolcs I (1989). Salt affected soils. CRC Press, Boca Raton, Florida, USA.

Tan KH,Nopamornbodi V (1979). Effects of different levels of humic acids on nutrient content and growth of corn (Zea mays L.). Plant and Soil 51:283-287.

Tanaka M, Fujiwara T (2007). Physiological roles and transport mechanisms of boron: perspectives from plants. Pflügers Archiv-European Journal of Physiology 456:671-677.
Tipping E (2002). Cation binding by humic substances. Cambridge University Press, Cambridge, U.K.No 12.

van Goor BJ, van Lune P (1980). Redistribution of potassium, boron, magnesium and calcium in apple trees determined by an indirect method. Physiologia Plantarum 48:21-26.

Wilcox LV (1960). Boron injury to plants, Agriculture information bulletin no. 211 Agricultural Research Service. United States Department of Agriculture, Washington, D.C.

Yau SK, Saxena MC (1997). Variation in growth development and yield of durum wheat in response to high soil boron I: Average effects. Australian Journal of Agricultural Research 48:945-949. 